\title{
Gap Intepretation About Period Punctuation in Instant Messages Among Indonesian Generation
}

\author{
Revanya Adira Corazan Junor \\ Communication Department, Faculty of Social and Political Sciences, Universitas Airlangga, \\ Jalan Dharmawangsa Dalam 4-6, Indonesia. \\ Email: revanya.adira.corazan-2017@fisip.unair.ac.id
}

\begin{abstract}
A B S T R A C T
This study discusses the factors that influence the interpretation gap between Generation $X$ and Millennials in Indonesia regarding Period Punctuation in instant messages. Since the chat communication style emerged due to the popularity of instant message applications, the period has lost its function as a pause and/or at the end of a sentence. Previous research states that a period is a weapon to show irony, cynicism, aggression, and insincerity. The period does not only end a message, but it is the message itself. Millennials use periods to express anger, while Generation X doesn't see any meaning in the punctuation. This gap is called the interpretation gap, influenced by the generational aspect. This research uses a qualitative approach with in-depth interviews focused on Generation $X$ and Indonesian Millennials. The results of this study indicate that the writing style in instant messaging will imitate the speaking style of face-to-face conversations. Generation $X$ tends to resolve conflicts in a to-the-point and assertive manner, while Millennials tend to be passive-aggressive and avoid confrontation. This fact is at the root of the choice of symbols they use to express anger through IM media.
\end{abstract}

Keywords: period mark, generational gap, Generation X, Millennials, instant message

A B S T R A C T

Penelitian ini membahas mengenai faktor-faktor yang mempengaruhi interpretation gap antara Generasi $\mathrm{X}$ dan Millennials Indonesia tentang tanda baca titik pada instant message. Sejak gaya komunikasi chatting muncul akibat populernya aplikasi instant message, tanda titik kehilangan fungsinya sebagai pemberi jeda dan pengakhir kalimat. Penelitian-penelitian terdahulu menyebutkan bahwa tanda titik merupakan sebuah senjata untuk menunjukkan ironi, nada sinis, sikap agresif, dan ketidaktulusan. Tanda titik tidak hanya mengakhiri sebuah pesan, namun ia adalah pesan itu sendiri. Millennials menggunakan tanda titik untuk mengekspresikan kemarahan, sementara Generasi X tidak melihat adanya makna pada tanda baca tersebut. Kesenjangan pemahaman ini disebut sebagai interpretation gap yang dipengaruhi oleh aspek generasional. Penelitian ini menggunakan pendekatan kualitatif dengan tipe eksploratif. Teknik pengumpulan data dari penelitian ini adalah wawancara mendalam dengan Generasi X dan Millennials Indonesia. Hasil penelitian ini menunjukkan bahwa gaya penulisan dalam instant messaging akan mengimitasi gaya bicara pada percakapan tatap wajah. Generasi X cenderung menyelesaikan konflik secara to-thepoint dan tegas, sementara Millennials cenderung bersikap pasif-agresif dan menghindari konfrontasi. Fakta ini merupakan akar dari pilihan simbol yang mereka gunakan untuk mengekspresikan kemarahan melalui media IM.

Kata kunci: tanda baca titik, kesenjangan generasional, Generasi X, Millennials, pesan instan

\section{A. INTRODUCTION}

The beginning of the instant messaging era was the end times of period mark (Bilefsky, 2016). Bilefsky reveals the death of the period puctuation in his writings by avoided use any full punctuation at all. The argument is that in conveying messages in online media, period is no longer needed. Some of the functions of one of the oldest punctuation marks in the world are 
starting to be replaced by other punctuation marks, or even not at all. According to Bilefsky, there are two main reasons behind the death of the period.

First, the period loses its function as a pause. Period was first coined by the ancient Greeks under the name punctus. Punctus was created with the simple goal of giving a pause in a play so that actors know where to stop (Houston, 2013). Now, in the context of CMC, communicators can pause by using whatever they want. Two other pauses that are most popular in the world of chatting to replace periods are commas and ellipsis. The refusal to not using period is also not a problem, because users can just send messages and give breaks in the form of line breaks.

The second reason is the period itself has begun to lose its function as a sign that ends sentences. Periods are also no longer used to separate one sentence from another. Linguistics professor David Crystal said in his book Language and the Internet that in a short message, a conversation never really ends. Even if it ends, it will be clear when the sentence is finished (Crystal, 2015). Periods are useless especially in short messages that only consist of one sentence, or even a few words that don't form a sentence structure. This idea is then reinforced by research from linguists Naomi Baron and Rich Ling, which states that the act of sending a message has the same function as a punctuation at the end of a sentence. Their results showed that in messages consisting of several sentences, punctuation marks were used to indicate the end of the sentence, but only $29 \%$ of the messages used punctuation at the end of the message. In conclusion, a simple way to end a sentence as well as a message is to simply hit send.

As Gretchen McCulloch mentions in his book, Because Internet: Understanding the New Rules of Language (2019), the use of period instant messages can be easily perceived as a passive-aggressive attitude. A period is not considered part of the message, so when it is finally used it is considered as additional information. Thus, this additional information requires additional interpretation (McCulloch, 2019). The semantic power possessed by this dot is then proven by research from Binghamton University \& Rutgers University which asked respondents to rate the same message on two different mediums. The message is only one word ending with a period (for example: "yes.") In the first medium, namely paper with handwritten messages, the majority of respondents admitted that the word contained no expression. However, in the second medium, namely the short message features on a social media, as many as $54 \%$ of respondents could feel the insincerity of the message. Other expressions that respondents can feel are anger and cynicism.

How period as punctuation mark is intepreted can be varied greatly for different individuals from different generations. According to research from The Washington Post, the same effect is not shown by Generation X (birth years 1965 - 1980 according to the theory of the Strauss-Howe generation). Generation $\mathrm{X}$ admits that they cannot recognize the context of intimidation conveyed by dots in short messages. This could be one of the reasons for the miscommunication that occurs between Generation X and Millennials. Research conducted by Ellen Groenestein of the Department of Communication Science, University of Twente, has similar results. 
Groenestein's research describes the strategies adolescents use to determine the age of an online stranger. In the study, two groups of teenage girls were asked to guess whether the online stranger was a teenager or an adult with sexual intentions. The result, they found several signs that differentiate between adolescents and adults, one of which is the use of language in the world of instant messaging. The use of language that is too formal, polite, and standard is a sign that the user is an adult. Unlike adults, teenagers write short messages as if they were talking. They don't think too much about grammar, spelling, or the use of traditional punctuation marks (Merchant, 2001).

The difference in speech patterns and the gap in understanding between the two generations is caused by digital communication technology which Generation X considers something foreign. Prensky in Vittadini (2013) calls Millennials as "digital natives" because they grow up surrounded by technology and use it at the same time. This terminology is based on the idea that members of this generation are "native speakers" of "digital languages." Donald Tapscott (2009), asserts that technology is completely invisible to children who grow up in the digital world, because for them technology is really "like air", means that technology is an inseparable part of today's society.

Digital technology generates new kinds of minds, especially for those born into it. Prensky also argues that young people are armed with new media so that they have a fundamentally different way of thinking than their predecessors. Confirming this statement, Marc Prensky said the technological environment is a "second nature" for digital natives. Millennials or digital natives are born into the digital world, so they don't know the analog world where letters are printed and sent let alone handwritten or understand how people get acquainted at formal dances instead of on Facebook. In contrast, Generation X as digital immigrants may have learned how to use email or even join social networks, but because this process occurs in the later stages of their lives, the digital world remains alien to them.

Writing styles have changed in a revolutionary way, especially the language of adolescents which develops rapidly (Rybnicek et al., 2013). One proof of this is the difference in the meaning of the period marks on instant messages between Generation $\mathrm{X}$ and Millennials (Generation Y). However, the Binghamton University study does not emphasize the power of the dot. The point is not about expressing insincerity using punctuation, but about how punctuation can only function as a message when the non-verbal language is understood by the communicant (Gunraj et al., 2016). The communicator must ensure that he has the same understanding with the communicant. Meanwhile, the generation gap can trigger conflict, create communication barriers, and disputes (Heng \& Yazdanifard, 2013).

This study aims to find answers to why there is a gap in understanding between Generation $\mathrm{X}$ and Millennials (Generation Y) about the context of anger that is carried by the punctuation of "Titik" in instant messages. This research is relevant to the scientific field of Communication, because this research discusses how generational identity can affect one's interpretation. A 
person's generation shapes his communication style and how he interprets a sign in a message. This research has high urgency because Generation $\mathrm{X}$ and Millennials in Indonesia often communicate with each other through instant messaging media.

The data collection technique in this study was to conduct in-depth interviews with 6 informants from each Generation $\mathrm{X}$ and Millennials. Researchers select informants who represent each gender equally, and from various socio-cultural backgrounds.

\section{B. RESULTS AND DISCUSSION}

From the results of in-depth interviews with informants, this study has found data that can reveal the reasons for the interpretation gap between Generation X and Millennials regarding the dot on instant messages. The data obtained have been analyzed using 3 main theories which are interconnected, and result in differences in the meaning of emojis, word writing, and punctuation.

\section{1) Formative Years Theory}

The first theory is the formative years theory, which states that a person's experience during the formative years (which is about 15-25 years) will leave a lasting impression on his life (van der Goot \& Beentjes, 2008). The media a person adopts as a teenager is one that he will likely use for the rest of his life.

Tabel 2.1 The age of the informant when he first accessed the instant message application

\begin{tabular}{lcccl}
\hline Informant & Years Born & $\begin{array}{c}\text { First time accessed } \\
\text { IM }\end{array}$ & $\begin{array}{c}\text { Age first time } \\
\text { accessing IM }\end{array}$ & Age \\
\hline ISW & 1970 & 2010 & 40 years & 50 years \\
M & 1976 & 2008 & 32 years & 44 years \\
HY & 1981 & 2008 & 27 years & 39 years \\
JDK & 1995 & 2009 & 14 years & 25 years \\
NPK & 1999 & 2011 & 12 years & 21 years \\
WMH & 2003 & 2013 & 10 years & 17 years \\
\hline
\end{tabular}

Source: the results of research interviews

Instant messaging applications (Yahoo Messenger, BBM, and WhatsApp) became popular when Generation X passed their formative years. Chatting is a new style of communication for them, which means that the style of writing punctuation in instant messaging is also a new language code that they do not fully understand. A period does not appear to be meaningful because for Generation $\mathrm{X}$ it only functions as a pause between sentences. The communication medium most favored by Generation $\mathrm{X}$ is the telephone. This proves the theory of formative years because by the time the telephone began to develop, Generation $\mathrm{X}$ was in its teens. 


\section{2) Media Usage Theory}

This data leads us to the second theory, namely the media use theory. Generation X's preferred medium of communication is telephones, while Millennials prefer instant messaging. Generation $\mathrm{X}$ is more comfortable communicating verbally and vocally in order to recognize the intonation conveyed by the message. Meanwhile, Millennials are still able to convey non-verbal signs through instant message media. Changes in the meaning of punctuation marks occur when the communication style of chatting begins to develop. Millennials are in their formative years so they can witness this development firsthand. Generation $X$ is not aware of the change in punctuation writing style because it is still loyal to telephone communication.

Generation $\mathrm{X}$ more often uses instant messaging as a medium of communication in a formal-professional context, so they are familiar with official language rules. Millennials interact more casually in instant messages, which mean they don't have to end sentences with a period punctuation. Finally, when this period is finally used, Millennials will feel that this is not normal and know that the message is implicit and high context (Romm, 2016).

Generation $\mathrm{X}$ tends to use emojis according to the expressions on the image, for example, using angry emojis when they are angry. Meanwhile, Millennials agree that the meaning of an emoji does not always match the expression seen. It can be concluded that Generation $\mathrm{X}$ tends to communicate in low context on instant messaging media. This fact explains why there are differences in the meaning of punctuation points between Generation X and Millennials in instant messages. The meaning of intimidation in the dot is in the context, so that it is not caught by the eyes of Generation $\mathrm{X}$ who are accustomed to interpreting written messages explicitly.

"Maybe if you're having a fight, for example, you talked at length and then the answer is just "okay.". So, in the end you are given a period mark. So, it sounded like he was talking: don't continue, it's better to give space first. The problem is that the period is usually used for formal messages. The impression is that if you use it in the chat, it's like sadistic. End the sentence with sadism. Anyway, "this is my statement. Stop. " Period."

(Informan WMH, Millennials, indepth interview November 2020)

"Sometimes people like to use period mark. Period like, what, give a more assertive impression? So, it really confirms that this is a serious discussion. Especially if this person rarely uses a dot then suddenly he uses a dot, that means he has something to say. He did emphasize something on purpose in his message. There are also people who when angry send smile emojis. It seems like sarcasm or cynicism."

(Informan NPK, Millennials, indepth interview November 2020)

\section{3) Generational Identity Theory}

The third theory that influences Generation $\mathrm{X}$ and Millennials' interpretation of dot punctuation is about their respective generational identities. Generation theory states that a person will tend to behave in accordance with how society perceives the identity of his generation. Logically, someone will use language understood by the group so that mutual understanding and communication can occur. This explains why even though everyone has a 
different chat style, they still adhere to the "standard of writing" of their respective generation. Therefore, the difference in chatting style between Generation $\mathrm{X}$ and Millennials can be recognized through several aspects such as the speed of replying to messages, writing words, using emojis, and using punctuation. The conclusion that can be drawn from these findings is that the generational identity is something that is real and recognized by each generation.

The following table shows the differences in punctuation interpretations and writing styles according to Generation X and Millennials.

Tabel 2.2 Understanding gap between Generation X and Millennials on instant messaging

\begin{tabular}{c|cc}
\hline $\begin{array}{c}\text { Punctuation interpretation and } \\
\text { writing style }\end{array}$ & $\mathbf{X}$ & Generation \\
\hline Smiley emoji & Happy & Sarcasm/lennials \\
Caps lock & Angry & Excited \\
Exclamation mark & Angry & Excited \\
Dot & Neutral & Angry \\
\hline
\end{tabular}

Source: the results of research interviews

Generation $\mathrm{X}$ relies on vocal messages (voice) that can be conveyed by telephone media to determine the expression of a person's message. Without hearing a voice, Generation $\mathrm{X}$ found it difficult to interpret the meaning of the message sender. Generation $X$ is not always able to read the intonation of an article. Punctuation marks that can be read into the intonation are question marks and exclamation marks.

"There should be (intonation in punctuation), but it's really hard to read. That's the bad taste of WA. That's why I often ask permission to call. Because by phone, even though we don't look at our faces, see facial expressions, eyes, and smiles or anything, at least we can create smiling faces. But writing is a bit confusing to guess someone's expression."

(informan ISW, Generasi X, indepth interview November 2020)

"Yes (read intonation in punctuation). Exclamation marks can, question marks can, but not much commas. If there are a lot of questions, it means they must be answered immediately. If the exclamation mark means angry."

(informan M, Generasi X, indepth interview November 2020)

In Instant Messaging communication, the communicant is given a very large space to interpret the message. We read the text of Instant Messaging messages according to the tone, volume, and speed of reading according to our own brains. This meaning depends on what components are considered part of the message according to the communicant. Generation X considers only words and emojis to be components of messages. Meanwhile, Millennials also 
consider punctuation as a guide to determine a person's nonverbal language.

Nonverbal language is more ambiguous and contextual than verbal messages. Guidelines for the meaning of nonverbal messages are not included and stipulated in linguistic rules. So, how far the communicator analyzes the message depends on our knowledge about which is part of the message. When communicators receive messages, they are receiving a lot of information at once through our senses. The information can be either verbal or nonverbal. There are also many types of nonverbal messages - there are kinesics, haptics, proxemics, and so on. Communicators need to interact with enough people to be able to deposit all of that data, so that when they are faced with a similar symbol, they already understand how to intepret it.

"As for Millennials, I don't see that there is any difference (the use of punctuation marks), huh. Because in terms of language delivery, about semicolons and others, the normative is that when we take the same formal education, logically we will use the same punctuation."

(informan ISW, Generasi X, indepth interview November 2020)

"My generation when interpreting punctuation is not as extreme as Millennials. If we just use it as a sign of pause. I still think they (Millennials) really accept Indonesian language lessons. They should come back again, remember the material they got when they were in elementary and junior high school. The KBBI has not changed."

(informan M, Generasi X, indepth interview November 2020)

"If on WhatsApp, in my opinion, it's almost the same as the others, yes, but what's different is the social media behavior."

(informan HY, Generasi X, indepth interview November 2020)

It can be concluded that Generation $\mathrm{X}$ is not aware of the change in period mark which initially only functioned as the end of sentences, now also functioned as intonation givers. Experience is an important factor for intepretation process of nonverbal language. Communicators interpret the message as far as what they want to analyze. Communicators will interpret nonverbal messages based on what experiences they associate with the message. So whatever the signs - volume of voice, intonation, speed of speech, emojis, to punctuation marks - it can only serves as a guide when communcators already have enough data in our brains to act as a "dictionary". Generation X hasn't interacted with enough people who use punctuation as a nonverbal language code in IM. Even now, Generation X does not consider punctuation as part of the message - it's just a guide to the inter-sentence breaks. Generation X does not feel that punctuation carries meaning because they never associate punctuation symbols with certain feelings.

For Generation X, if a message in Instant Messaging can be expressed verbally, there is no need to use nonverbal signs anymore. Even if Generation $\mathrm{X}$ wants to convey indirect or implicit messages they will still use words. Millennials on the other hand think that the components of an Instant Messaging message include much more than just words - that is, through punctuation as well. When Millennials want to encode a message, they will think of period mark as an 
expression variable. Period mark is considered as an alternative to provide certain information. Communicators will analyze the Instant Messaging messages they receive to write punctuation as well.

Period mark cannot fully function as symbols because they do not have any meaning when they stand alone. However, we still cannot rely on words alone to define the meaning of the message, as the WMH informant explained below.

"Maybe for sarcasm or for that? For example, saying, "haha really." That would be completely different from 'haha that's really true' for which no point was given. Reading it is like laughing, right?"

(Informan WMH, Millennials, indepth interview November 2020)

Of course, communicators can still rely on the context of the message to determine how to interpret it - whether or not there was a conflict in the conversation. However, from the example given by $\mathrm{WMH}$, the phrase 'haha that's really true' is something to say in response to a joke. It could be that a conversation before 'haha that's really right' that ends with a period is fine. The communicant may be faced with a situation that he thinks is fun, but the communicator tries to give clues about the emotions he is hiding. As in face-to-face conversations, nonverbal messages also have the function of contradicting verbal messages.

Period mark completes sentences, just as nonverbal messages complement verbal messages. Although it has no meaning standing alone, period mark contributes to determining the meaning of an Instant Messaging message. An analogy that can help understand this concept is about volume. In face-to-face conversation if someone speaks at a high volume but doesn't speak, we won't be able to translate what he means. One still has to speak the words that other people understand. The meaning of the message will depend on the words conveyed. If the words he shouted were, "Hey! Don't be rude!" then the high volume serves as a suppression of anger. If the shout is in the form of words like, "Come on! You can do it!" then the function of the large volume is to provide positive energy such as support/encouragement. Both sentences if expressed in lower volume will not be able to convey the full meaning of the message. However if the volume aspect is not considered part of the message, the communicant can analyze the meaning of the message using other aspects, such as facial expressions. The advantage of face-to-face conversations is that vocal nonverbal messages are not limited to one aspect. The meaning of a message can be determined through intonation, volume of voice, expression, and speed of speech. Text in IM messages is not intonated. There are no guidelines for the tone, volume, or speed at which a message is conveyed.

From the data collected it can be concluded that Millennials have a higher context communication style than Generation X. In fact, in general, Generation X can also communicate in high contexts in Instant Messaging. The informants came from more or less the same culture, namely Javanese which has a high context culture. In general, as long as they live in the same culture, the forms of communication tend to be the same. Generation X can also use satire or 
convey implicit messages via Instant Messaging. However, the form of the message they convey is still in the form of words - in contrast to Millennials who use punctuation to add context to the message. All informants of this study were asked about how to tease people through Instant Messaging, and the ISW informant as a Generation X replied, " How do I do it ... even though it's actually not good and it is not allowed, maybe just through words. How else? ". The HY informant, Generation X, answered the same thing, "Yes, you can (teasing people through IM), you really can. I usually use figurative language. Just through words."

\section{CONCLUSION}

Generation $\mathrm{X}$ associates the shape and size of writing with volume. This finding was supported by the statement of the informants from Generation $X$ that if they wanted to show anger, they would write the message in all capital letters. The ISW informant also added, "If the writing can be bold, it's better to be bold as well." This shows the emphasis in the context of assertiveness, that: I am angry. This code is based on their attitude towards face-to-face conversation, that is, they turn up the volume when they are angry.

Millennials don't see caps locks as a sign of anger, because turning up the volume isn't their way of showing anger. While Millennials also associate the shape and size of writing with volume, they interpret using caps lock in IM as a sign of enthusiasm. Millennials often raise the volume for a positive context, which is to provide support or encouragement. In essence, Generation $\mathrm{X}$ and Millennials will have a writing style that matches how they express themselves in the real world.

The period mark is born as a symbol that carries the context of anger because of the basic function of a period to end sentences, and the way Millennials express anger in face-to-face conversations is by stopping the conversation while being cool. Millennials informants in this study answered compactly that their way to show anger in IM was to reply to messages in a cool, cold, and brief manner. This contrasts with Generation X, which shows anger assertively by emphasizing exclamation points, caps locks, and angry emojis.

In conclusion, the writing style in instant messaging will imitate the speaking style of face-to-face conversations. Generation $\mathrm{X}$ tends to resolve conflicts in a to-the-point and assertive manner, while Millennials tend to be passive-aggressive and avoid confrontation. This fact is at the root of the choice of symbols they use to express anger through IM media.

\section{BIBLIOGRAPHY}

Bilefsky, D. (2016). Period. Full Stop. Point. Whatever It's Called, It's Going Out of Style.

Crystal, D. (2015). Making a Point: The Pernickety Story of English Punctuation. Profile Books.

Gunraj, D. N., Drumm-Hewitt, A. M., Dashow, E. M., Upadhyay, S. S. N., \& Klin, C. M. (2016). Texting insincerely: The role of the period in text messaging. Computers in Human Behavior, 55, 10671075. https://doi.org/10.1016/j.chb.2015.11.003 
Heng, C. Y., \& Yazdanifard, R. (2013). Generation Gap ; Is There any Solid Solution? From Human Relation Point of View. International Journal of Economy, Management and Social Sciences, 2(10), 837-840.

Houston, K. (2013). Shady Characters. W. W. Norton \& Company.

Ling, R., \& Baron, N. S. (2007). Text Messaging and IM. Journal of Language and Social Psychology, 26(3), 291-298. https://doi.org/10.1177/0261927x06303480

McCulloch, G. (2019). Because Internet: Understanding the New Rules of Language. Riverhead Books.

Merchant(01). (2001). Teenagers in cyberspace: Language use and language change in chatrooms. Journal of Research in Reading, 24(3), 293-306.

Romm, C. (2016). Linguistics Explains Why Ending a Text With a Period Makes You Seem Like a Monster. https://www.huffpost.com/entry/linguistics-explains-why_b_11411544

Rybnicek, M., Poisel, R., \& Tjoa, S. (2013). Facebook watchdog: A research agenda for detecting online grooming and bullying activities. Proceedings - 2013 IEEE International Conference on Systems, Man, and Cybernetics, SMC 2013, 2854-2859. https://doi.org/10.1109/SMC.2013.487

van der Goot, M., \& Beentjes, J. W. J. (2008). Media Use across the Life-Span. The International Encyclopedia of Communication. https://doi.org/10.1002/9781405186407.wbiecm055 